\title{
PILED EMBANKMENT DESIGN COMPARISON
}

\author{
Marián DRUSA ${ }^{1,{ }^{*}}$, Ladislav KAIS ${ }^{1}$, Jozef VLČEK ${ }^{1}$, Martin MEČÁR ${ }^{2}$ \\ ${ }^{1}$ Department of Geotechnics, Faculty of Civil Engineering, University of Žilina, Univerzitná 8215/1, \\ 01026 Žilina. \\ 2 Department of Railway Engineering, Faculty of Civil Engineering, University of Žilina, Univerzitná \\ 8215/1, 01026 Žilina. \\ * corresponding author: marian.drusa@fstav.uniza.sk, +421-4-1513 5755.
}

\begin{abstract}
There are currently several national standards or regulations for the design of the piled embankment, providing suitable solutions for foundation of transport structure on soft, high compressible subsoil, [1]. The most widely used and the best-known standard is British Standard BS8006 [2], which was confronted with another analytical design methodologies (Ebgeo, CUR). Today's popularity and versatility of FEM numerical models brings many advantages, which analytical methods cannot achieved, but must be verified by proposed scaled physical model, which was currently being developed by Department of Geotechnics, University of Žilina.
\end{abstract}

\author{
Keywords: \\ Piled embankment; \\ Physical model; \\ Arching; \\ Soft subsoil; \\ Reinforcement; \\ Geogrids.
}

\section{Introduction}

The realization of transport constructions is often associated with the necessity to build special geotechnical structure in places because of presence of soft and high compressible subsoil, generally called unfavorable geotechnical conditions. These types of subsoil are characterized by a small bearing capacity and high compressibility through the time, which affects the selection process for establishment of such structures. Therefore, designers are forced to seek new implementation of solutions. Such new solutions might include the foundation of embankments on piles - popular as 'piled embankment'. The first piled embankment construction was made in early 70's of last century in Finland. It was build using large pile heads without reinforcing materials at the basal layer. This type of structure was later proved to be very successful and progressive for the foundation of embankments on soft subsoil.

Shortly thereafter, in the 70's, the presented structure was significantly modified. Basal reinforcement by high tensile strength polyester geosynthetics (geogrids) was added to the layer in contact with subsoil. This type of structure was firstly used in the UK in central Scotland on the A876 road in 1973. [1, 2].

The piled embankment foundation with basal reinforcement over underpinned piles is not the only possible solution for unfavorable geotechnical conditions. Furthermore, alternatives of this method are:

- dynamic compaction, impact compaction known as rapid consolidation,

- additional load of subgrade of embankment before its completion (preconsolidation),

- reinforcing at the base of the embankment by geosynthetics (basal reinforcement), [3],

- speed up consolidation by drainage ribs - Iongitudinal or transverse to the axis of the embankment,

- gravel piles and vibro-stone columns (stone columns),

- thorough mixing and improvement of soil properties in the ground (deep soil mixing),

- grouting of subsoil (jet grouting),

- massive or partial soil replacement of subsoil by heavily compressible and organic soils (massive replacement),

- using of lightweight structural materials of embankment (e.g. expanded polystyrene EPS), [4].

The main reason for using the foundation of an embankment on piles with reinforced basal layer is the guarantee of a minimum settlement and deformation at very compressible soil. Another 
advantage is the short construction time, compared to other technologies, and the feasibility of construction during the wintertime. The Fig. 1 shows principle of piled embankment transport structure.

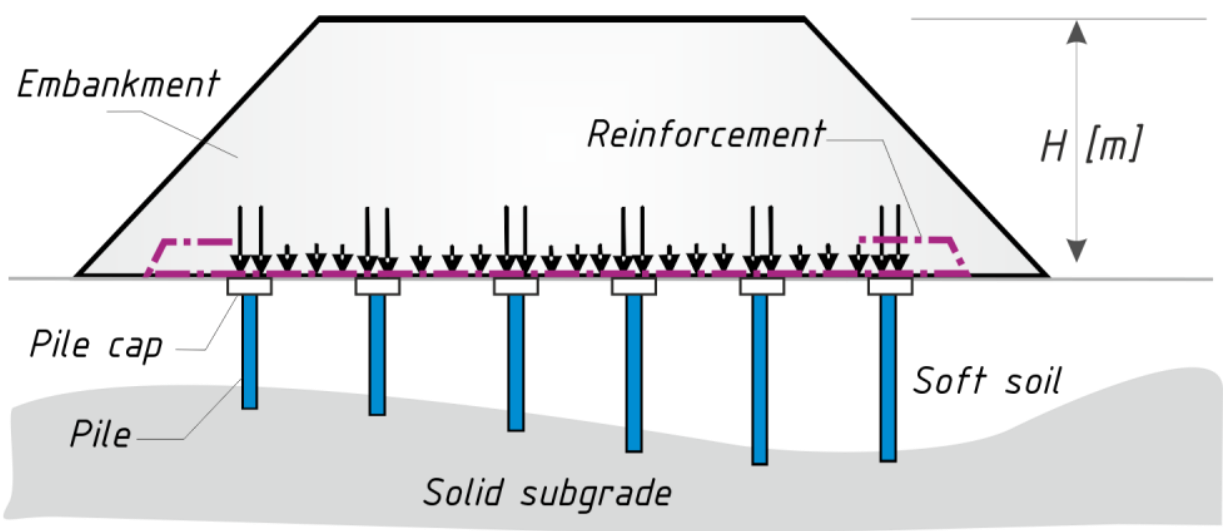

Fig. 1: Piled embankment structure, [4].

\section{Principle of piled embankment load distribution}

The mechanism of load distribution in the embankment differs, depending on the part being investigated. It needs to be distinguished between the distribution of the load at embankment slopes part and distribution inside the embankment. Load distribution inside the embankment is based merely on the arch effect, while at the slope parts of the embankment, there is sliding due to lateral movement of the slope sides. In this article, however, we will deal exclusively with load distribution inside the embankment, where focusing on arching creation.

For an explanation, arched effect or in English literature 'arching' was firstly defined by McNulty in 1965 [6] as 'the ability of a material to transfer load from one place to another in response to a relative decline between points'. This is acting due to the shear stress in the mechanism, by which the load is transmitted.

For a better explanation of active forces in this type of construction, it is necessary to divide overall burden stress into the three parts:

- load from the traffic and self-weight transmitted into the pile directly or through the arch effect - marked on Fig. 2 as part of the A load,

- the remaining load under the arch, which is not directly transmitted to the pile by arching effect, creating vertical load on the geosynthetic reinforcement - part B load. This load causes deformation of the geosynthetic reinforcement, which generates tensile forces in the reinforcement, which are then transmitted to the pile. Piles then carried out not just the A load part, but also B load into the deeper bearable layer,

- part C load, as the load carried by the subsoil (partial soil support) is not taken into account in case of BS8006.
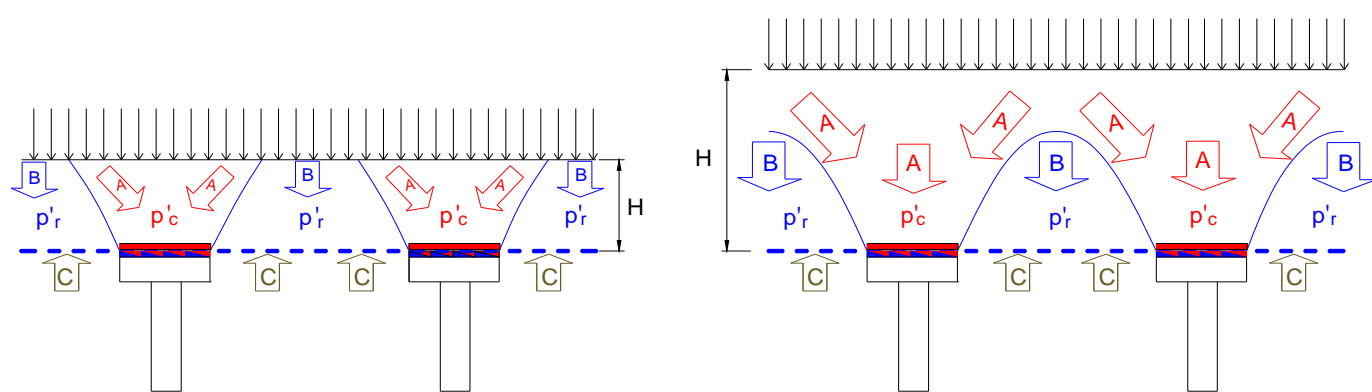

Fig. 2: Model of arching for partial and full arch creation, part C is neglected in BS 8006. 


\section{Calculation methodology}

Most of analytical design models used for the design of piled embankment with basal reinforcement layer divide calculation into two steps, Fig. 3:

- the first step is to investigate the influence of arch effect in the embankment (arching behavior in the fill). This step is called as a step of forming arches, which divides the total vertical load in two parts - part $A$ and remaining load of part $B$.

- the second calculation step describes the deformation of the geosynthetic reinforcement, by acting remaining load of part $\mathrm{B}$, applied to the strip geosynthetic reinforcement between adjacent piles and determines its deformation and consequently a tensile stress.

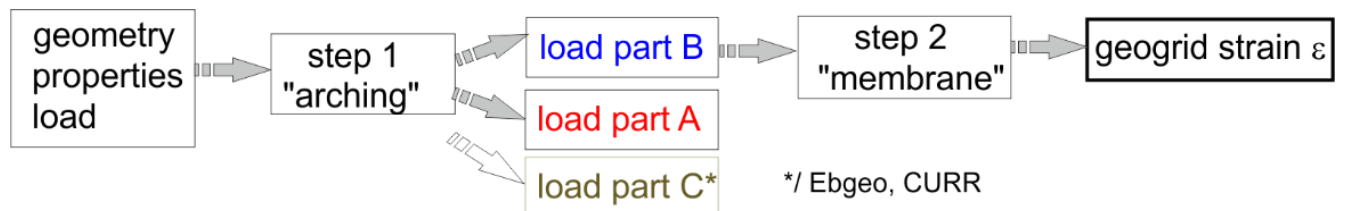

Fig. 3: Principle of calculation of piled embankment.

\section{1 Analytical models}

Analytical models are used as a basic design methodology for designing earth structure geometry and reinforcement of piled embankment, especially for estimation of the tensile strength in a basal reinforcement. These models are adequately supported by physical and numerical models.

\section{2 BS8006 model}

The long-standing comprehensive model, that describes the design of the piled embankment with basal reinforcements is the British Standard BS8006 [7], which was first published in 1995 and followed while the last revision in 2010. The BS8006 model (Fig. 4) is based on an analysis of Marston and Anderson's theory (1913) [7], which originated in experiments carried out using a pipe in a trench having filled up with soil. These equations describing the arch effect in 2D situation are based on the pipe diameter, height of the embankment and the arching coefficient, as defined, for different types of soil.

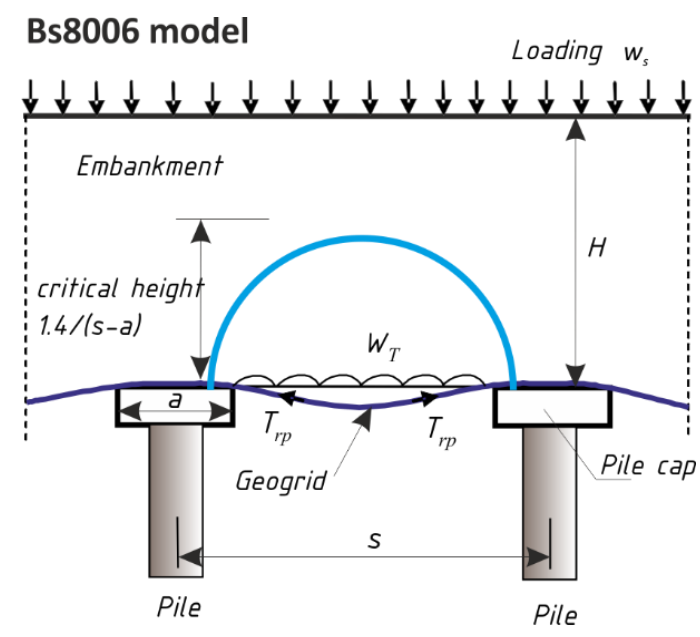

Fig. 1: Principle of design.

Subsequently, this theory was modified to its present form by group of authors around John [7], which in 1987 was adjusted to the original equation in 3D with square piles. 
Equations for the coefficient of arch action (arching coefficient), which contains the height of the embankment, the width of the pile head and its type (end-bearing piles, friction piles) were introduced.

$$
\frac{P_{c}^{\prime}}{\sigma_{v}^{\prime}}=\frac{C_{C} a}{H} \rightarrow \frac{P_{c}^{\prime}}{\sigma_{v}^{\prime}}=\left[\frac{C_{C} a}{H}\right]^{2},
$$

where: $P_{c}$ ' - vertical stress on pile head,

$\mathrm{C}_{\mathrm{c}}$ - soil arching coefficient,

$\sigma_{v}{ }^{\prime}$ - average vertical stress on foundation soil (base), and other symbols explained in Fig. 4.

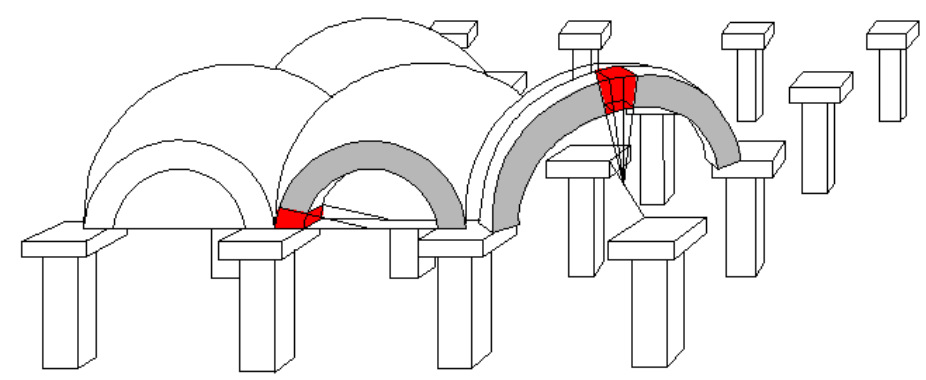

Fig. 5: Model of 3D arching according to Hewlett \& Randolph (1988), [7]

This method is based on the theory of determining the efficiency $E$, being defined as the ratio by weight of the embankment supported by piles from whole weight. The proportion of the weight carried by the embankment reinforcement - geogrids (GGR), can be determined from the relation 1 - $E$. The weight of the embankment directly supported by piles should be determined in two places:

- at place of top of arch,

$$
E_{\text {crown }}=1-\frac{\left(s^{2}-a^{2}\right)}{s^{2} \gamma H}\left[\sigma_{i}+\gamma(s-a) / \sqrt{2}\right] \text {, }
$$

- on pile head,

$E_{\text {cap }}=\frac{\beta}{1+\beta}$,

where:

$$
\beta \frac{2 \mathrm{~K}_{\mathrm{p}}}{\left(K_{p}+1\right) \cdot\left(1+\frac{a}{s}\right)}\left[\left(1-\frac{a}{s}\right)^{-K_{p}}-\left(1+K_{p} \frac{a}{s}\right)\right] .
$$

Calculation of the tensile force in the reinforcement $T_{r p}$ by BS 8006 [7] terms can be determined:

$$
T_{r p}=\frac{W_{T}(s-a)}{2 a} \sqrt{1+\frac{1}{6 \varepsilon}},
$$

where: $W_{T}$ - represents the vertical load carried by the reinforcement between adjacent piles heads, at the average strain of reinforcement $\varepsilon$,

$a$ - the diameter of the pile head,

$s$ - the axial distance of piles. 
In the next calculation step, according to modified model set by John [8] is necessary to determine the embankment height $H$, from which depending whether it is the creation of a full arching (for $\mathrm{H}>1.4(\mathrm{~s}-\mathrm{a})$ ) or partial arching (for $\mathrm{H}$ from interval $0.7(\mathrm{~s}-\mathrm{a}) \leq \mathrm{H} \leq 1.4(\mathrm{~s}-\mathrm{a})$ ).

To determine the maximum load $W_{T}$ carried by geogrids between adjacent piles, in the case of the model by Hewlett and Randolph [7] should be determined as minimal efficiency $E_{\min }$. This represents the lower value from ratio $E_{\text {crown }} / E_{\text {cap }}$.

From this theory study about optimization of piled embankment geometry, related to indicated tensile forces were introduced [2,5].

\section{Scaled physical model of piled embankment}

Multiple theories with engineering solutions of piled embankment structure, with simple physical and numerical models were published. They meet practice, a state also called computing equilibrium.

A new-scaled physical model of structure has been started by the Faculty of Civil Engineering, Department of Geotechnics, (FCE KGt) and firstly was analyzed by using Plaxis 3D Foundation software models. The scale model (Fig. 6) is formed by 16 supported piles of $300 \mathrm{~mm}$ height and $100 \mathrm{~mm}$ of cross section diameter. Piles of PVC material are fixed to the concrete slab layer in order to simulate end-bearing piles. Very-soft subsoil is simulated by plastic foam (molitan) with low load capacity. Two perpendicular uniaxial geogrids (GGR), type Enkagrid 40, are placed on the pile heads. For the backfill, crushed stone fraction of $0 / 16 \mathrm{~mm}$ was selected. Static load on the backfill surface is provided by 4 hydraulic jacks in the range between $25 \mathrm{kPa}$ and $100 \mathrm{kPa}$.
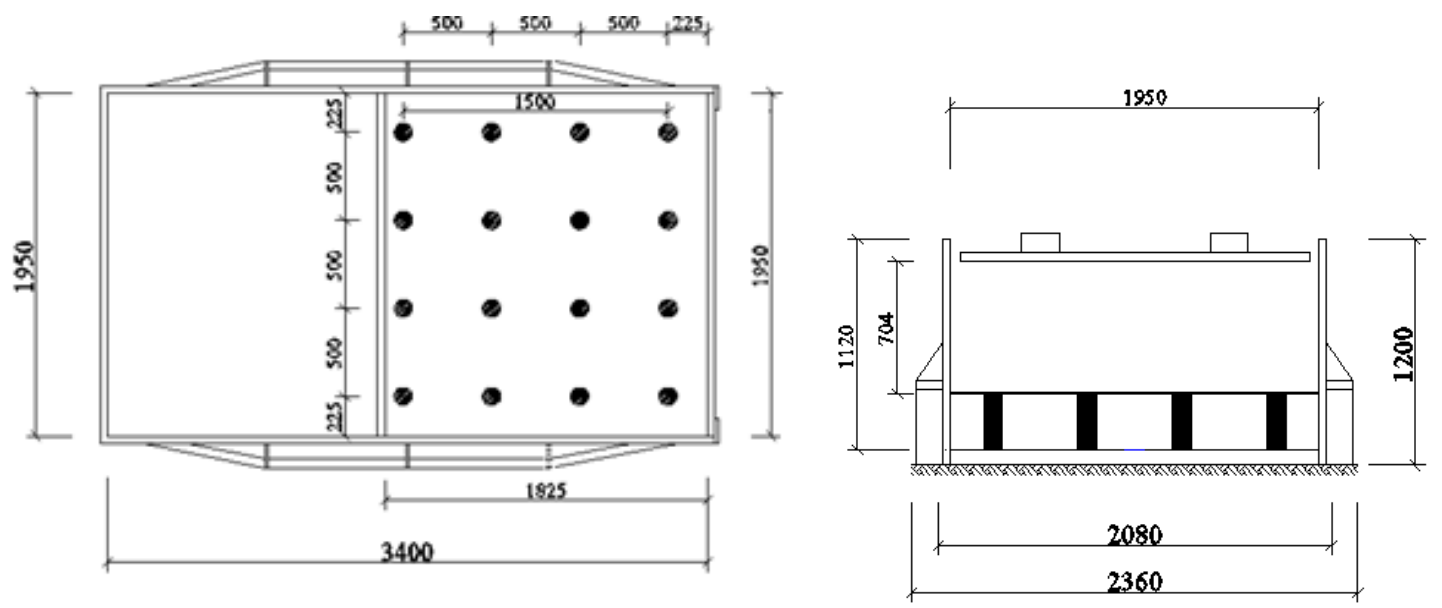

Fig. 6: Model stand of FCE KGt 2015.

\section{Numerical modeling}

The numerical analysis is carried out in seven calculation steps. At each step there was simulated an increase of the embankment height by $10 \mathrm{~cm}$, which had one load cycle of $100 \mathrm{kPa}$. The configuration of the scaled model uses backfill material definition of the Hardening Soil (HS) model, [9]. The following Table 1 shows used values of input parameters. From these values were compared results of provided calculations by analytical and numerical methods, Fig. 7 . The curves showing the courses of the tensile force in accordance to embankment height, method of calculation and place of calculated point. The results of BS 8006 starts from the value creation of the full arching, in this case curve arises when the value of the height is $0.576 \mathrm{~m}$. This is documented large dispersion of values between partial and full arching effect, which is more than 10 times. However, calculated tensile forces are higher than FEM 3D Plaxis model results. This is influenced also by position of observed tensile stress in FEM model (in the middle of piles, closed to cap, and at place of pile head), which corresponding well with physical models of arching of other authors, where distribution of tensile force through the geogrids between piles has triangular shape [10]. The results also show limitation of BS8006 calculation usage for small embankment heights. 
There is a recommendation to respect critical height of embankment at case of modified structures of embankment, e.g. at the design of heavy loaded floor support or counting partial subsoil support. In any other type of calculated structures, FEM analysis is more versatile to predict tensile forces.

Table 1: Input parameters of numerical models.

\begin{tabular}{|c|c|c|c|c|c|c|}
\hline \multicolumn{4}{|c|}{ Material properties of soils } & \multicolumn{3}{|c|}{ Material properties of beams } \\
\hline Parameter & Name & $\begin{array}{l}\text { Subsoil } \\
\text { - foam }\end{array}$ & $\begin{array}{l}\text { Granular } \\
\text { fill HS }\end{array}$ & Parameter & Name & Pile \\
\hline Material model & Model & $\begin{array}{l}\text { Linear } \\
\text { elastic }\end{array}$ & \begin{tabular}{|l}
$\begin{array}{l}\text { Hardening } \\
\text { soil }\end{array}$ \\
\end{tabular} & Material type & Type & Linear \\
\hline Drainage type & Type & Drained & Drained & Cross-section area & $\mathrm{A}\left[\mathrm{m}^{2}\right]$ & $7.854 \cdot 10^{-3}$ \\
\hline Soil unit weight above gwl. & $\begin{array}{c}\gamma \text { unsat } \\
{\left[\mathrm{kN} \cdot \mathrm{m}^{-3}\right]}\end{array}$ & 0.16 & 18 & Unit weight & $\gamma\left[\mathrm{kN} \cdot \mathrm{m}^{-3}\right]$ & 13.90 \\
\hline Soil unit weight below gwl. & $\begin{array}{c}\gamma_{\mathrm{sat}} \\
{\left[\mathrm{kN} \cdot \mathrm{m}^{-3}\right]}\end{array}$ & 0.16 & 18 & Young's modulus & $\mathrm{E}[\mathrm{kPa}]$ & $2.9 \cdot 10^{6}$ \\
\hline $\begin{array}{l}\text { Young's modulus at } \\
\text { reference level }\end{array}$ & $\begin{array}{l}\text { E'ref } \\
{[\mathrm{kPa}]}\end{array}$ & 500 & - & $\begin{array}{l}\text { Moments of inertia } \\
\text { (against horizontal } \\
\text { bending) }\end{array}$ & $\mathrm{I}_{2}\left[\mathrm{~m}^{4}\right]$ & $4.909 \cdot 10^{-6}$ \\
\hline $\begin{array}{l}\text { Secant stiffness in } \\
\text { standard } \\
\text { drained triaxial test }\end{array}$ & $\begin{array}{l}\mathrm{E}_{50}{ }^{\mathrm{ref}} \\
{[\mathrm{kPa}]}\end{array}$ & - & $5 \cdot 10^{4}$ & $\begin{array}{l}\text { Moments of inertia } \\
\text { (against vertical } \\
\text { bending) }\end{array}$ & $\mathrm{I}_{3}\left[\mathrm{~m}^{4}\right]$ & $4.909 \cdot 10^{-6}$ \\
\hline $\begin{array}{l}\text { Unloading / reloading } \\
\text { stiffness }\end{array}$ & $\begin{array}{l}\text { Eurt } \\
{[\mathrm{kPa}]}\end{array}$ & - & $1.5 \cdot 10^{5}$ & & & \\
\hline $\begin{array}{l}\text { Power for stress-level } \\
\text { dependency of stiffness }\end{array}$ & {$[\mathrm{m}]$} & - & 0.75 & \multicolumn{3}{|c|}{$\begin{array}{l}\text { Material properties of floors (geogrid } \\
\text { replacement) }\end{array}$} \\
\hline Cohesion & $\mathrm{c}^{\prime}[\mathrm{kPa}]$ & - & 1 & Parameter & Name & Geogrid \\
\hline Friction angle & $\varphi^{\prime}\left[{ }^{\circ}\right]$ & - & 42 & Material type & Type & Linear \\
\hline Dilatancy angle & $\psi \quad\left[^{\circ}\right]$ & - & 12 & $\begin{array}{l}\text { Equivalent } \\
\text { thickness }\end{array}$ & $\mathrm{D}[\mathrm{m}]$ & $1.87 \cdot 10^{-4}$ \\
\hline Poisson's ratio & $v^{\prime}$ & 0.3 & - & Unit weight & $\gamma\left[\mathrm{kN} \cdot \mathrm{m}^{-3}\right]$ & 11.75 \\
\hline $\begin{array}{l}\text { Poisson's ratio for elastic } \\
\text { unloading/reloading }\end{array}$ & $v^{\prime}$ ur & - & 0.2 & $\begin{array}{l}\begin{array}{l}\text { Young's modulus } \\
\text { (isotropic) }\end{array} \\
\end{array}$ & $\mathrm{E}[\mathrm{kPa}]$ & $4 \cdot 10^{6}$ \\
\hline $\begin{array}{l}\text { Reference stress for } \\
\text { stiffness }\end{array}$ & $\begin{array}{c}\mathrm{p}^{\mathrm{ret}} \\
{\left[\mathrm{kN} \cdot \mathrm{m}^{-2}\right]}\end{array}$ & - & 100 & \multirow{5}{*}{\multicolumn{3}{|c|}{ a }} \\
\hline $\begin{array}{l}K_{0} \text {-value for normal } \\
\text { consolidation }\end{array}$ & $\mathrm{K}_{0}^{\mathrm{nc}}$ & - & 0.331 & & & \\
\hline Failure ratio & $\mathrm{R}_{\mathrm{f}}$ & - & 0.9 & & & \\
\hline Interface strength type & Type & Manual & Manual & & & \\
\hline Interface strength & $R_{\text {inter }}$ & 0.5 & 0.9 & & & \\
\hline
\end{tabular}

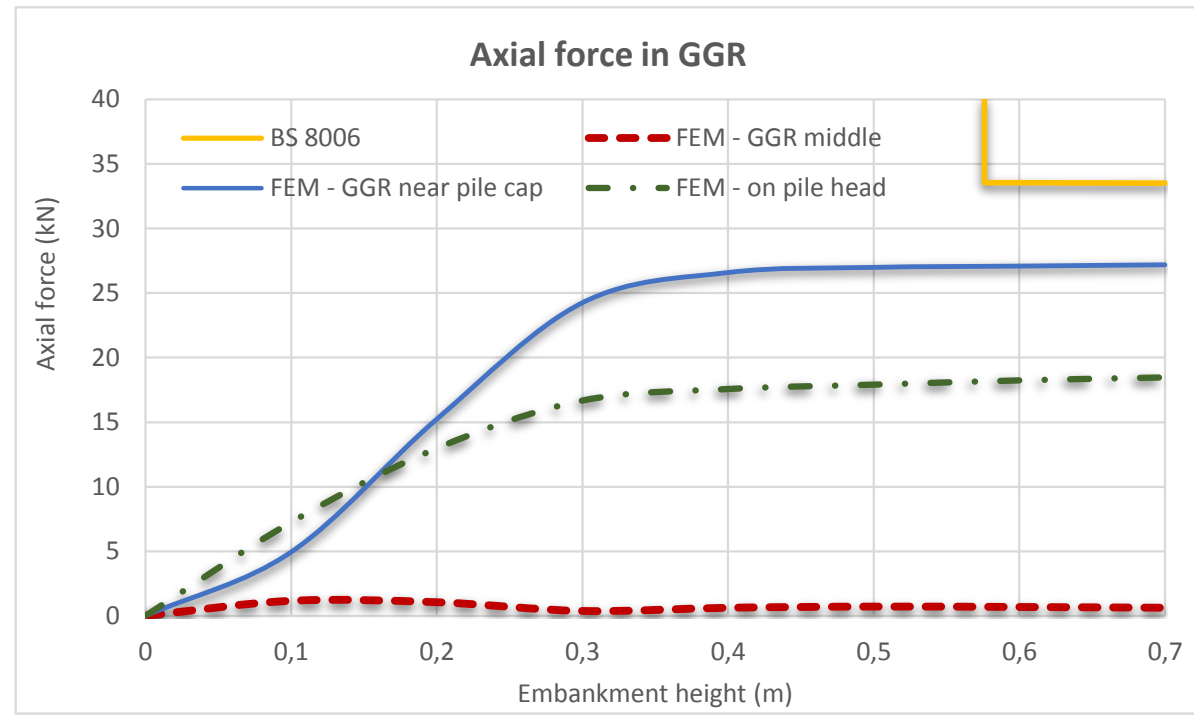

Fig. 7: Results of analytical and numerical calculation of tensile forces in geogrids according to height of embankment. 


\section{Conclusions}

In comparison, the presented numerical and analytical calculations show advantages of detailed FEM analyses. One of the advantages of numerical modeling lies in proving the geometry of proposed scaled physical model of FCE KGt 2015. The optimal piled embankment structure can be designed only when suitable calculation methodology is introduced. Therefore, scaled physical models and real time geotechnical monitoring of these structures are required. The same problems occurred with designing of structures similar to piled embankment, e.g. heavy loaded floor on soft subsoil supported by piles, or stone columns. As introduced in this article, validation of calculation should be done using a proposed scaled physical model, where arching effect creation and increase of loading in basal reinforcement can be measured. This, in return, helps to distinguish which stage of construction is riskier for final design evaluation.

\section{References}

[1] REID, W. M. - BUCHANAN, N. W.: 1984. Bridge approach piling, Piling and Ground treatment, Thomas Telford Ltd, London.

[2] PRELOVSKY, B. - NAUGHTON, P. J. - SCOTTO, M. - KEMPTON, G. T.: The Development of Piled Embankments Techniques Over 25 Years.

[3] DRUSA, M. - LAMICH, D. et al.: Design Limits of Reinforced Soil Structures in Difficult Geological Conditions, In: SGEM 2013 Proceedings, DOI:10.5593/SGEM2013/BA1.V2/S02.010.

[4] DECKÝ, M. - DRUSA, M. - PEPUCHA, L'. - ZGÚTOVÁ, K.: Earth Structures of Transport Constructions. Harlow: Essex: Pearson, pp.180, 2013, ISBN 978-1-78399-925-5.

[5] DRUSA, M. - PRELOVSKÝ, B. - NAUGHTON, P.: Optimization study of basal reinforcement of the piled embankment on soft subsoils, Proceedings of the 5th International Conference on Geosynthetics in constructions, Žilina 2009, ISBN 978-80-8070-977-8 (in Slovak).

[6] MCNULTY, J. W.: (1965). An Experimental study of arching in sand." Technical Report No. I- 674, U.S. Army Engineer Waterways Experiment Station, Corps of Engineers, Vicksburg, Mississippi, 170.

[7] BS8006-1, revision 2010. Code of Practice for Strengthened/reinforced Soils and Other Fills. British Standards Institution.

[8] TARA VAN DER PEET: Arching in basal reinforced piled embankments, dissertation thesis TU Delft 2014.

[9] MUŽík, J.: Analysis of Geotechnical Structures Using Meshless Local Petrov-Galerkin Radial Point Interpolation Method, In: SGEM2014 GeoConference Proceedings, ISBN 978-619-7105-087 / ISSN 1314-2704, June 19-25, 2014, Vol. 2, 41-48 pp. DOI: 10.5593/SGEM2014/B12/S2.006.

[10]VAN EEKELEN, S. J. M. - BEZUIJEN, A.: Design of Piled Embankments, Considering the Basic Starting Points of The British Standard BS8006. Proceedings of Eurogeo4, $4^{\text {th }}$ European Geosynthetics Conference, Edinburgh, $7^{\text {th }}$ to $10^{\text {th }}$ September 2008. 